\title{
Educational Satisfaction of Public Health Undergraduates: A cross sectional study in Nepal
}

\author{
${ }^{1}$ Sudarshan Subedi, ${ }^{1}$ Hari Prasad Kaphle, ${ }^{1}$ Roshan Neupane, ${ }^{1}$ Roshna Rajbhandari
}

${ }^{1}$ School of Health and Allied Sciences, Pokhara University

\begin{abstract}
Educational satisfaction determines the quality of education system which interns affects the performance and achievement of students during study and finally future professional competencies. The objectives of this study were to identify the perceived status of satisfaction on educational conditions and teaching-learning environment and associated factors of it among the public health undergraduates. This was the descriptive cross sectional study carried out among 384 undergraduate students of public health studying in final year/semester of three universities of Nepal using self administered questionnaire. The result of the study showed that satisfactions on various components are below than average. Among the satisfied components, the major were in case of duration of course (46.1\%), teaching skills of part time teacher (39.1\%), curriculum and overall course of study (36.2\%), research/dissertation guidance (34.6\%) and teaching skills of full time teacher (33.6\%). The satisfaction level was least in case of result timing/procedure (14.1\%), tuition fee (23.7\%), examination procedure (26.3\%) and evaluation system (27.1\%). Ethnicity, educational background, course duration, types of teacher, availability of books in library and availability of research papers/journals were found associated with educational satisfaction. The study concluded low educational satisfaction among public health under graduate students. It is recommended to take immediate action for improvements of different components of education system like curriculum structure \& contains, teaching methodology, teaching learning materials, admission and examination procedure.
\end{abstract}

Key words: Public health; Education; undergraduate course; satisfaction; Nepal

Corresponding address: Sudarshan Subedi, School of Health and Allied Sciences, Pokhara University.

E-mail: subedisudarshan@gmail.com

\section{INTRODUCTION}

The study of Public Health started in Nepal as an undergraduate degree i.e. Bachelor of Public Health (BPH) in 1986 at the Maharajgunj Campus of Tribhuvan University. After that, Purbanchal University started this course at 2001 followed by Pokhara University at 2005. The total colleges under different universities in Nepal are 24 with common annual enrollment of 40 students of each institution. If the annul intake capacity of university and its affiliated institutions is fulfilled, the total number of public health undergraduates produced annually become more than 900. Bachelor of Public Health course trains students in the basic and essential skills of public health aspects needed to plan and manage the health programs, ${ }^{1}$ basically at district level of the country. Graduates of this course can work as Public Health Officer in the government sector. Besides, there are other options to pursue professional career in non-governmental and private organizations in the field of epidemiology, environmental health, reproductive health, disease control, nutrition, research, training and so on.

Public health is a field outside four walls in which the professionals need to be engaged with different types of activities that are directly or indirectly public concern. Competency and quality in work, which is a must for public health professionals, initially arises from the course and curriculum of formal institution like university. Different factors are related with the educational system which may determine the status of satisfaction among the students. Educational satisfaction, a subjective aspect is generally the extent to which the learners (students) like or dislike the exposed system of teaching learning environment in a formal institution. It determines the fulfillment of all the educational expectations and needs of students. ${ }^{2}$ Determinants of educational satisfaction affects the student's educational commitment and the quality of learning ${ }^{2}$ which in turns affects their performance and achievement during study and finally the future competencies as concerned professionals. The objectives of this study were to identify the perceived status of satisfaction on educational conditions and teachinglearning environment and associated factors of it among the public health undergraduates.

\section{METHODS}

It was a cross sectional descriptive study carried out in three universities of Nepal which offer undergraduate courses in public health i.e. Bachelor of Public Health (BPH). Students studying at the final year and/or final semester of selected colleges of three universities were the study population. Assuming the prevalence of educational satisfaction as $50 \%$ with probable error 5\%, the sample size was 384 . Sampling frame was developed as per the total number of students in different colleges under three universities. Based on the 
sampling frame, proportionate to population size (PPS) was used to identify the number of sample from each college of three universities. Finally, simple random sampling was adopted to select the study unit.

Self administered questionnaire was used to collect the related data and information from the respondents. Questionnaires were distributed after making respondents aware about the study purpose and the ways of filling up the questionnaire; assistance and probing was done as per the need. Regarding the selection criteria, those students of intuitions in which the researcher did not get permission, those who refused to participate and those who were irregular in colleges and/ or absent during the day of data collection were excluded. Field editing was carried out and questionnaires were checked before the entry. Data was entered in Epi Data v3.1 and analyzed using Statistical Package for Social Sciences (SPSS) v16.0. Results of analysis are expressed in term of descriptive and inferential statistics.

In order to get the exact information, questionnaire was made practicable and convenient. Pre-testing was done and changes were made in alternative responses of questions in the questionnaire. The study was approved and permission granted by Research Center of Pokhara University. The purpose of study was clearly informed to the concerned authority of selected colleges as well as to the respondents. Anonymity was emphasized and maintained regarding the name of colleges under university to make it confidential. Verbal consent was taken prior to administration of questionnaire to the students. Voluntarily participation and right to refuse were followed. All the information collected is utilized only for the study purpose.

\section{RESULTS}

\section{A. Educational Institutions, Course Duration and Enrollment Characteristics}

Regarding the distribution of respondents, majority were from Purbanchal University with least from Tribhuvan University $(8.1 \%)$ as per their annual enrollment in the colleges. Students studying 3 years course were almost two third $(63.5 \%)$ who were from Purbanchal and Tribhuvan University as compared to 4 years course $(36.5 \%)$ from Pokhara University. (Table 1)

Table 1: Distribution of respondents according to educational institution and duration of course

\begin{tabular}{|l|l|l|}
\hline \multicolumn{1}{|c|}{ Characteristics } & Frequency & Percentage \\
\hline Educational Institution & & \\
Tribhuvan University & 31 & 8.1 \\
Pokhara University & 140 & 36.5 \\
Purbanchal University & 213 & 55.5 \\
\hline $\begin{array}{l}\text { Location of Educational } \\
\text { Institution }\end{array}$ & 303 & 78.01 \\
Inside Kathmandu valley & 81 & 21.09 \\
Outside Kathmandu valley & & \\
\hline Duration of course & 244 & 63.5 \\
3 years & 140 & 36.5 \\
4 years & \\
\hline
\end{tabular}

Public health course is open to both general science and health science background in Nepal. The study revealed that majority $(70.3 \%)$ of the students studying were from general science background with not engaged in job prior to study (79.7\%); those who were exposed to job were mostly the medical/health personnel. (Table 2)

Table 2: Prior education and employment

\begin{tabular}{|l|l|l|}
\hline \multicolumn{1}{|c|}{ Variables } & Frequency & Percentage \\
\hline Prior education area $(\mathbf{n = 3 8 4})$ & & \\
General science & 270 & 70.3 \\
Health sciences & 114 & 29.7 \\
\hline Prior status of job $(\mathbf{n}=\mathbf{3 8 4})$ & & \\
Yes & 78 & 20.3 \\
No & 306 & 79.7 \\
\hline Prior areas of job $(\mathbf{n}=\mathbf{7 8 )}$ & & \\
Health sector & 50 & 64.1 \\
Non health sector & 28 & 35.9 \\
\hline
\end{tabular}

\section{B. Reasons for selecting course and university}

Reasons for choosing both the course and university were identified in the study. The major reasons for choosing BPH course were desire to change career path $(34.6 \%)$, parents/ relatives recommendation $(31 \%)$ and perception to find a job easily $(19 \%)$. On the other hand, students basically choose the university and/or colleges by the perceived status of good quality education (25.0\%), physically accessible and timely acceptable (24.2\%), financially affordable (17.2\%) and being easy to got admission $(15.4 \%)$. BPH course was found to be of first choice among $57.6 \%$, others selected this course as an alternative. (Table 3)

Table 3: Reasons to pursue BPH course

\begin{tabular}{|c|c|c|}
\hline Reasons & Frequency & Percentage \\
\hline $\begin{array}{l}\text { To choose BPH course } \\
\text { Easy to find a job } \\
\text { Parents /relatives recommended } \\
\text { Forced to admit the course } \\
\text { Got a scholarship for the course } \\
\text { Wanted to change the career path } \\
\text { Others }\end{array}$ & \begin{tabular}{|l}
73 \\
119 \\
14 \\
31 \\
133 \\
14
\end{tabular} & $\begin{array}{l}19.0 \\
31.0 \\
3.6 \\
8.1 \\
34.6 \\
3.6\end{array}$ \\
\hline \multicolumn{3}{|l|}{ To choose university } \\
\hline Being the university of choice & 23 & 6.0 \\
\hline Being physically and timely acceptable & 93 & 24.2 \\
\hline Being financially affordable & 66 & 17.2 \\
\hline Due to good quality education & 96 & 25.0 \\
\hline Being easy to get admission & 59 & 15.4 \\
\hline Getting scholarship & 27 & 7.0 \\
\hline Being not able to get admission to other & 15 & 3.9 \\
\hline Others & 5 & 1.3 \\
\hline \multicolumn{3}{|l|}{ BPH course as $1^{\text {st }}$ priority or alternative } \\
\hline $\begin{array}{l}\text { First choice and intended to admit in BPH } \\
\text { only }\end{array}$ & 221 & 57.6 \\
\hline $\begin{array}{l}\text { Intended to other course but did not get } \\
\text { admission over there }\end{array}$ & 141 & 36.7 \\
\hline $\begin{array}{l}\text { Intended to admit in other course but got } \\
\text { scholarship in BPH }\end{array}$ & 22 & 5.7 \\
\hline
\end{tabular}




\section{Educational Materials and Teaching Learning Environment}

The status of the availability of educational materials as perceived by the students was also identified in the form of textbooks/reference books and research papers/journals in the library. More than half $(62.5 \%)$ of respondents reported the moderate with $21.1 \%$ least availability whereas only $16.4 \%$ reported sufficient availability. The degree availability of research papers/journals is same as the textbook/reference books i.e. almost half $(48.7 \%)$ of respondents reported the moderate availability with $39.8 \%$ least availability whereas only $11.5 \%$ reported sufficient availability.

In context of method of study, majority $(82.3 \%)$ of respondents learned via lecture method whereas very few (4.7\%) of them were engaged in the opportunities of seminar and related. More than three fourth $(76.6 \%)$ of respondents were dependent on teachers note as a basis for study and only $23.4 \%$ of respondents consulted the library, internet and the like. Regarding the way of teaching, preference is almost same as per the types of teacher i.e. full time and part time whereas in context of level of teacher, student prefer the teaching style of lecturer (39.1\%) followed by professor $(34.1 \%)$ and associate professor (26.8\%). (Table 4)

Table 4: Method, basis and preference for study

\begin{tabular}{|l|l|l|}
\hline \multicolumn{1}{|c|}{ Variables } & Frequency & \multicolumn{1}{c|}{ Percentage } \\
\hline Major method of teaching & 316 & 82.3 \\
Lecture & 50 & 13.0 \\
Group Discussion & 18 & 4.7 \\
Seminar and Others & 294 & 76.6 \\
\hline Major basis for study & 90 & 23.4 \\
Teachers' note & 152 & 39.6 \\
Others (library, internet, others) & 202 & 52.6 \\
\hline Use of web search & 30 & 7.8 \\
Maximum & & \\
Moderate & 239 & 62.2 \\
Minimum & 114 & 29.7 \\
\hline Use of curriculum & 21 & 5.5 \\
Maximum & 10 & 2.6 \\
Sometimes & & \\
Seldom & 190 & 49.5 \\
Never & 194 & 50.5 \\
\hline Prefer Teaching & & 39.1 \\
(type of teacher) & Full time teacher & 26.8 \\
Part time teacher & 150 & 34.1 \\
\hline Level of teacher & 103 & \\
Lecture & 131 & \\
Associate Professor & Professor &
\end{tabular}

\section{View on curriculum and subject matter}

Results on respondents' view on curriculum and course of $\mathrm{BPH}$ revealed that the perception on duration of BPH course as appropriate and desirable was above average $(58.9 \%)$ whereas the respondent's perception on design of curriculum (46.1\%) and focus of curriculum on key areas $(47.7 \%)$ were slightly below average. Noticeable parts of curriculum was the updating system and specification of appropriate reference materials in which the proportion of disagree outweigh the proportion of agree i.e. only $20.3 \%$ and $32.3 \%$ were concurred in the concerned matter respectively.

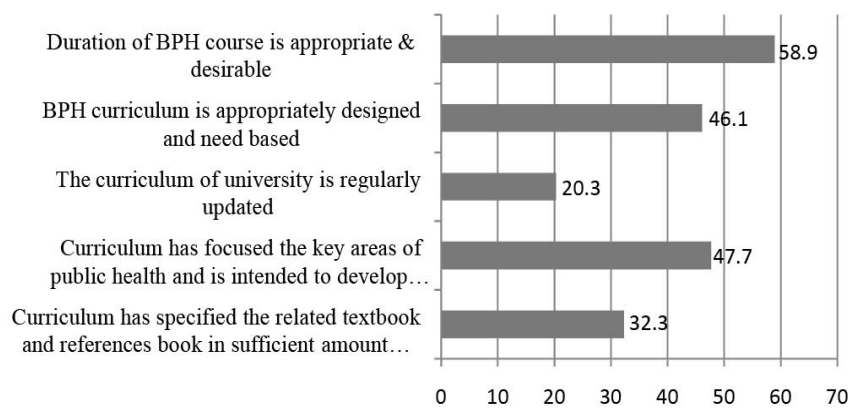

Figure 1: Respondent's view on BPH course curriculum of concerned university (\% of agree)

Results in context of respondent's perception about the areas covered/emphasize by BPH course found that Maternal \& Child Health (57.8\%), Epidemiology (54.0\%), Research Methodology (49.7\%) and Reproductive Health \& Family Planning $(46.4 \%)$ were the mostly focused subjects. The less covered areas felt by the respondents were health seminar (17.7\%), demography (17.2\%) and sociology and anthropology (25\%).

Table 6: Respondent's view on emphasis of subject matter in $\mathrm{BPH}$ course

\begin{tabular}{|l|l|l|l|}
\hline \multicolumn{1}{|c|}{ Subject Areas } & \multicolumn{1}{|c|}{$\begin{array}{c}\text { Less } \\
\text { emphasize }\end{array}$} & $\begin{array}{c}\text { Moderately } \\
\text { emphasize }\end{array}$ & \multicolumn{1}{|c|}{$\begin{array}{c}\text { Highly } \\
\text { emphasize }\end{array}$} \\
\hline Primary Health Care & $26(6.8 \%)$ & $169(44.0 \%)$ & $189(49.2 \%)$ \\
\hline RH and Family Planning & $31(8.1 \%)$ & $175(45.6 \%)$ & $178(46.4 \%)$ \\
\hline Maternal and Child Health & $20(5.2 \%)$ & $142(37.0 \%)$ & $222(57.8 \%)$ \\
\hline Epidemiology & $22(5.7 \%)$ & $155(40.3 \%)$ & $207(54.0 \%)$ \\
\hline Research Methodology & $46(12.0 \%)$ & $147(38.3 \%)$ & $191(49.7 \%)$ \\
\hline Demography & $113(29.4 \%)$ & $205(53.4 \%)$ & $66(17.2 \%)$ \\
\hline $\begin{array}{l}\text { Health Policy, Plans } \\
\text { and Programs }\end{array}$ & $62(16.1 \%)$ & $173(45.1 \%)$ & $149(38.8 \%)$ \\
\hline $\begin{array}{l}\text { Health Education and } \\
\text { Promotion }\end{array}$ & $43(11.2 \%)$ & $174(45.3 \%)$ & $167(43.5 \%)$ \\
\hline $\begin{array}{l}\text { Human Resource } \\
\text { Management }\end{array}$ & $54(14.1 \%)$ & $186(48.4 \%)$ & $144(37.5 \%)$ \\
\hline $\begin{array}{l}\text { Environment and } \\
\text { Occupational Health }\end{array}$ & $32(8.3 \%)$ & $188(49.0 \%)$ & $164(42.7 \%)$ \\
\hline Food and Nutrition & $52(13.5 \%)$ & $176(45.8 \%)$ & $156(40.6 \%)$ \\
\hline Biostatistics & $62(16.1 \%)$ & $156(40.6 \%)$ & $166(43.2 \%)$ \\
\hline Sociology and Anthropology & $74(19.3 \%)$ & $214(55.7 \%)$ & $96(25.0 \%)$ \\
\hline Health Seminar & $167(43.5 \%)$ & $149(38.8 \%)$ & $68(17.7 \%)$ \\
\hline Field visit & $81(21.1 \%)$ & $138(35.9 \%)$ & $165(43.0 \%)$ \\
\hline
\end{tabular}

The level of confidence of BPH students in applying the skills required for job that were learned during the course of study was also studied. The subject areas in which the students are more confidence to apply are Maternal and Child Health $(52.3 \%)$, Food and Nutrition (49.5\%), Health Promotion and Education (46.6\%) and Reproductive Health and Family Planning $(46.4 \%)$. The areas in which students were less confidence were Demography (20.6\%), Health Policy, Plans and Programs (16.7\%) and Biostatistics (15.1\%). (Table 7) 
Table 7: Respondent's confidence in applying the skills learned

\begin{tabular}{|l|l|l|l|}
\hline \multicolumn{1}{|c|}{ Subject area } & Less confidence & Moderate confidence & Strong confidence \\
\hline Primary Health Care & $35(9.1 \%)$ & $196(51.0 \%)$ & $153(39.8 \%)$ \\
\hline $\begin{array}{l}\text { Reproductive } \\
\text { Health and FP }\end{array}$ & $23(6.0 \%)$ & $183(47.7 \%)$ & $178(46.4 \%)$ \\
\hline Maternal and Child Health & $24(6.2 \%)$ & $159(41.4 \%)$ & $201(52.3 \%)$ \\
\hline Epidemiology & $44(11.5 \%)$ & $210(54.6 \%)$ & $130(33.9 \%)$ \\
\hline Research Methodology & $51(13.3 \%)$ & $204(53.1 \%)$ & $129(33.6 \%)$ \\
\hline Demography & $79(20.6 \%)$ & $239(62.2 \%)$ & $66(17.2 \%)$ \\
\hline $\begin{array}{l}\text { Health Policy, Plans and } \\
\text { Programs }\end{array}$ & $64(16.7 \%)$ & $215(56.0 \%)$ & $105(27.3 \%)$ \\
\hline $\begin{array}{l}\text { Health Education and } \\
\text { Promotion }\end{array}$ & $18(4.7 \%)$ & $187(48.7 \%)$ & $179(46.6 \%)$ \\
\hline $\begin{array}{l}\text { Human Resource } \\
\text { Management }\end{array}$ & $51(13.3 \%)$ & $219(57.0 \%)$ & $114(29.7 \%)$ \\
\hline $\begin{array}{l}\text { Env and Occupational } \\
\text { Health }\end{array}$ & $26(6.8 \%)$ & $196(51.0 \%)$ & $162(42.2 \%)$ \\
\hline Food and Nutrition & $21(5.5 \%)$ & $173(45.1 \%)$ & $190(49.5 \%)$ \\
\hline Biostatistics & $58(15.1 \%)$ & $224(58.3 \%)$ & $102(26.6 \%)$ \\
\hline $\begin{array}{l}\text { Sociology and } \\
\text { anthropology }\end{array}$ & $44(11.5 \%)$ & $219(57.0 \%)$ & $121(31.5 \%)$ \\
\hline
\end{tabular}

\section{E. Satisfaction status and associated factors}

The result showed that the level of satisfaction on every aspect is below average (excluding the neutral). However, among the satisfied components, the major were in case of duration of course (46.1\%), teaching skills of part time teacher $(39.1 \%)$, curriculum and overall course of study $(36.2 \%)$, research/dissertation guidance $(34.6 \%)$ and teaching skills of full time teacher $(33.6 \%)$. The satisfaction level was least in case of result timing/procedure (14.1\%), tuition fee $(23.7 \%)$, examination procedure $(26.3 \%)$ and evaluation system (27.1\%). (Fig. 2)

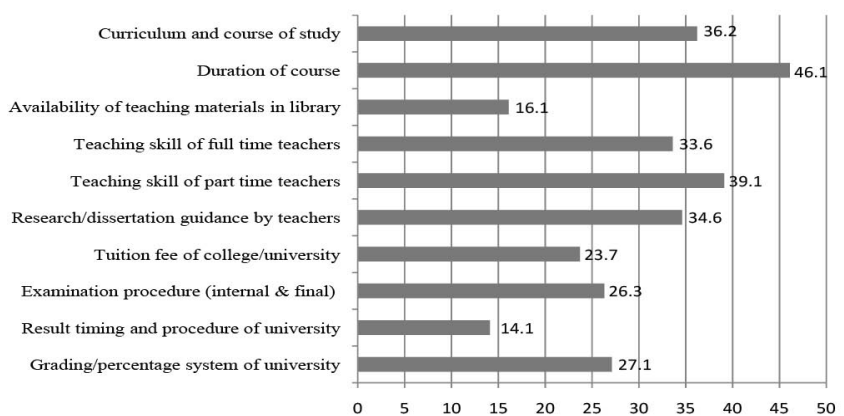

Figure 2: Respondent's satisfaction on different aspects of $B P H$ course $(\%)$

Analysis showed that variables like ethnicity $(p=0.01)$, educational background $(p=0.01)$, course duration $(p<0.001)$, types of teacher $(\mathrm{p}<0.001)$, availability of books in library $(p<0.001)$ and availability of research papers/journals $(\mathrm{p}<0.001)$ were found to be associated with educational satisfaction. Respondents from upper casts were 1.8 times more satisfied than the others. Similarly, respondents having educational background in health sciences and studying 3 years course were 1.7 and 2.2 times more satisfied than the adjacent. Regarding the educational environment, studying with full time teacher, availability of books in library and availability of research papers/journal were significant factors that increase the education satisfaction by $2.3,2.3$ and 4.3 folds respectively.

Table 7: Factors associated with educational satisfaction

\begin{tabular}{|c|c|c|c|c|c|}
\hline \multirow{2}{*}{ Variables } & \multicolumn{2}{|c|}{ Satisfaction } & \multirow{2}{*}{ P value } & \multirow{2}{*}{\begin{tabular}{|l|} 
Odds \\
Ratio \\
\end{tabular}} & \multirow{2}{*}{$\begin{array}{c}\text { CI } \\
\text { (lower - upper ) }\end{array}$} \\
\hline & Yes & No & & & \\
\hline $\begin{array}{l}\text { Ethnicity } \\
\text { Brahmin/Chhetri } \\
\text { Janajati/Others }\end{array}$ & $\begin{array}{l}122 \\
37\end{array}$ & $\begin{array}{l}145 \\
80\end{array}$ & 0.01 & 1.8 & $95 \%(1.15-2.87)$ \\
\hline \begin{tabular}{|l|} 
Educational background \\
Health science \\
General science \\
\end{tabular} & \begin{tabular}{|l}
58 \\
101 \\
\end{tabular} & \begin{tabular}{|l|}
56 \\
169 \\
\end{tabular} & 0.01 & 1.7 & $95 \%(1.11-2.69)$ \\
\hline $\begin{array}{l}\text { Duration of course } \\
3 \text { years } \\
4 \text { years }\end{array}$ & $\begin{array}{l}118 \\
41\end{array}$ & $\begin{array}{l}126 \\
99\end{array}$ & $<0.001$ & 2.26 & $95 \%(1.4-3.5)$ \\
\hline $\begin{array}{l}\text { Type of teacher } \\
\text { Full time } \\
\text { Part time }\end{array}$ & $\begin{array}{l}98 \\
61\end{array}$ & $\begin{array}{l}92 \\
133\end{array}$ & $<0.001$ & 2.32 & $95 \%(1.53-3.52)$ \\
\hline $\begin{array}{l}\text { Availability of books in } \\
\text { library } \\
\text { Sufficient/Moderate } \\
\text { Least }\end{array}$ & $\begin{array}{l}138 \\
21\end{array}$ & $\begin{array}{l}165 \\
60\end{array}$ & $<0.001$ & 2.3 & $95 \%(1.38-4.12)$ \\
\hline $\begin{array}{l}\text { Availability of research } \\
\text { papers/journals in } \\
\text { library } \\
\text { Sufficient/Moderate } \\
\text { Least }\end{array}$ & $\begin{array}{l}126 \\
33\end{array}$ & $\begin{array}{l}105 \\
120\end{array}$ & $<0.001$ & 4.3 & $95 \%(2.74-6.94)$ \\
\hline
\end{tabular}

\section{DISCUSSION}

Out of total 24 institutions offering public health undergraduate in Nepal, only 5 lies outside capital city which is not corresponding the recommendation of WHO i.e. targeting the location of health professional schools/campuses and family medicine residency programs outside of capitals. ${ }^{3}$ The duration of public health undergraduate in Nepal was 3 years and 4 years (at the time of study) and the eligibility criterion stated by the universities of Nepal is the $12^{\text {th }}$ class with general science or health science. Students from general science background wanted to change their career path, the cause of which they enrolled in public health course. Among the many courses of medical and health sciences in Nepal, MBBS always seems to be the first choice. Others to be in priority are nursing, pharmacy, laboratory and public health, the evidence of which are the record review of admission related procedures (number of applicants, priority setting by applicants, waiting list/time for admission and admission rate) in different universities. Public health course was the first choice of hardly sixty percent; rest of them selects it as an alternative. Dominancy of clinical medicine over public health ${ }^{4}$ and other subjects of allied health sciences could be one of the causes. Besides, the task of public health could not be seen and felt by the public like as in other allied health sciences which seems to be clinical in nature. Public health is a versatile discipline and the prospective professionals of it should be familiar with different sort of knowledge, ideas and skills which are developed by the method of teaching learning process in the institutions. Lecture and teacher's hands out (note) being the dominant method and 
basis for study respectively may raise a question on how the learned knowledge would be applied in an effective way of delivering services in the future. Moreover, the curriculum, which is the major basis of providing education running without update for so many years will not able to address the dynamism of environment viz. changes in nature/area of work, national/international health policies/laws, health interventions and others, is found to be the major weaknesses felt by the consumers of it.

Educational satisfaction plays a vital role in increasing the competencies among the students which is generally associated with so many factors like as classroom size, academic level, availability of library resources ${ }^{5}$, age of students, technology used. ${ }^{6}$ Although there may variability between educational institution in teaching methods, contents and resources, ${ }^{7}$ the methods and modes of instruction ${ }^{5}$ are predominantly associated with educational satisfaction among students. The aspects studied in the study were the availability and types of faculties, provision of teaching materials and other facilities, the curriculum structure and related aspects, education and employment background, etc. As stated earlier, students from health science background had their exposure in fundamentals of public health or other allied health sector, the conditions of which was found to have increased level of educational satisfaction. Use of internet in public health course of Nepal is very common due to inadequate faculties and very limited availability of textbook and reference books in library. Students not only accept 'google' as the professor but also claimed to have more books in their cohort than the library. ${ }^{4}$ It's demonstrated by the study that having books and research papers/journals in library increase the satisfaction of undergraduates by twice and fourth time respectively. It's now a need to increase the supply of competent faculties and combine the traditional lecture method with more innovative and problem-based approach ${ }^{7}$ to bring out the educational satisfaction and thereby increasing the capabilities of prospective public health professionals.

Public health undergraduate course with 3 years duration has now been a matter of past. All the universities in Nepal implemented the standard duration of 4 years in public health undergraduate. Most of the respondents for this study were the last batch of three years course duration. The study found that duration of course was associated with educational satisfaction, three years being more satisfied than four years. It may raise the issue of expansion in course duration but this matter is later discussed and triangulated as one of the predictors of career plan to with the career plan result is also discussed with the predictor of career plan.

Shortage of trained public health faculties is the major problem in universities/colleges of $\mathrm{Nepal}^{4}$ which is generally accepted by both the provider and clients of educational system. This condition could be more or less, directly or indirectly related with the educational satisfaction among the students. Educational satisfaction could be the cause, which, if supported by inadequate opportunities for processional growth and development, would be the strong predictor of brain drain in developing countries like Nepal.

\section{CONCLUSION}

Educational satisfaction, although linked with different factors and directly/indirectly influence the future of those, it is a serious matter of concern for educational institution and concerned officials because there are so many ways an educational institutions should and would do in order to make the educational environment more effective, the condition which obviously increase the satisfaction level and finally making the public health undergraduates more skillful and competent in the areas of public health.

\section{ACKNOWLEDGEMENTS}

Authors are highly appreciative to Pokhara University Research Center (PURC) for providing a grant to the study. Administration and students of constituent and affiliated colleges included in the study are also acknowledged.

\section{REFERENCES}

1. Samyangkham, B. Secure Future with Public Health? Available: http://www.educatenepal.com/career_articles/display/securefuture-with-public-health.,2011. [Accessed July 4, 2013].

2. Peters, DH, Chakraborty, S, Mahapatra, $\mathrm{P}$ and Steinhardt, L. Job satisfaction and motivation of health workers in public and private sectors: cross-sectional analysis from two Indian states. Human Resources for Health, 2010; 8.

3. Hayes, B and Shakya, R. Career choices and what influences Nepali medical students and young doctors: a cross-sectional study. Human Resources for Health, 2013; 11.

4. Mahat, A, Bezruchka, SA, Gonzales, V. and Connell, FA. Assessment of graduate public health education in Nepal and perceived needs of faculty and students. Human Resources for Health, 2013;11.

5. Anasari, W. and Oskrochi, R. What matters most? Predictors of student satisfaction in public health educational courses. Public Health, 2006; 120, 462-73.

6. So, H. Is blended learning a viable option in public health education? A case study of student satisfaction with a blended graduate course. J Public Health Manag Pract, 2009; 15, 59-66.

7. Gillam, S. and Bagade, A. Undergraduate public health education in UK medical schools struggling to deliver. Medical Education, 2006, 40. 